\title{
Meta
}

Journal des traducteurs

Translators' Journal

\section{The Exquisite Sophistication of French Scholarly Writing: French Spirit or French Letter?}

\section{Jacques Colson}

Volume 38, numéro 3, septembre 1993

URI : https://id.erudit.org/iderudit/002355ar

DOI : https://doi.org/10.7202/002355ar

Aller au sommaire du numéro

Éditeur(s)

Les Presses de l'Université de Montréal

ISSN

0026-0452 (imprimé)

1492-1421 (numérique)

Découvrir la revue

Citer cet article

Colson, J. (1993). The Exquisite Sophistication of French Scholarly Writing:

French Spirit or French Letter? Meta, 38(3), 426-439.

https://doi.org/10.7202/002355ar
Résumé de l'article

Le discours savant français contemporain se caractérise, du point de vue stylistique, par une recherche formelle très poussée qui ne semble pas présente dans les textes anglais équivalents. Cette réflexion vise à vérifier la validité de cette hypothèse en cernant la notion de discours savant et en définissant et comparant la notion de recherche formelle dans les deux langues. À la lumière de textes représentatifs et de leur traduction, on constate que l'hypothèse de départ se vérifie. Plusieurs explications, essentiellement sociolinguistiques, permettent d'en rendre compte. 


\title{
THE EXQUISITE SOPHISTICATION OF FRENCH SCHOLARLY WRITING: FRENCH SPIRIT OR FRENCH LETTER?
}

\author{
JACQUES COLSON \\ University of New Brunswick, Fredericton, Canada
}

\begin{abstract}
Résumé
Le discours savant français contemporain se caractérise, du point de vue stylistique, par une recherche formelle très poussée qui ne semble pas présente dans les textes anglais équivalents. Cette réflexion vise à vérifier la validité de cette hypothèse en cernant la notion de discours savant et en définissant et comparant la notion de recherche formelle dans les deux langues. À la lumière de textes représentatifs et de leur traduction, on constate que l'hypothèse de départ se vérifie. Plusieurs explications, essentiellement sociolinguistiques, permettent d'en rendre compte.
\end{abstract}

\begin{abstract}
One salient feature of contemporary French scholarly writing is its high degree of stylistic sophistication, which does not seem to be present in English. This paper examines the validity of this observation by attempting a definition of scholarly writing common to English and French, and by characterizing and comparing stylistic sophistication in both languages. Typical texts and their translations are then examined, which confirm the hypothesis, and sociolinguistic explanations are suggested to account for it.
\end{abstract}

If sophistication may be a cliché to describe the French concept of style in general, it certainly is a reality when it comes to French scholarly writing. If one has not been trained in the proper use of this register, one can, nevertheless, learn to master it by studying M. Burnier and P. Rambaud's Roland Barthes sans peine.

This book is a parody which, as far as I know, has no equivalent in English. Not that there is no stylistic sophistication to be parodied in the English-speaking world, but gobbledygook seems to be as far as one has gone in that exercise. One merit of this parody - as of all parodies - is to reveal what appears as a salient feature of French scholarly writing: its elaborate, ornate, finely honed wording. If the fact is striking to the educated speaker of French (Burnier and Rambaud certainly qualify as such), it can only be more so to the educated speaker of English, providing he (or she, of course) has an equivalent command of French, which should be the case with translators. If a translator is also theoretically minded, he (or she) is bound to ask a number of questions in his reflections on the theory of translation, or on the translation of "theory", understood as a synonym for "scholarly writing".

Just what is it that makes French scholarly writing so unique? If there is no equivalent in English, how does one go about translating it? Conversely, how does one translate English scholarly writing into French? To suggest answers to these and similar questions, it makes sense first to define the notion of style and then identify "scholarly writing" in both French and English. A full-scale statistical investigation is beyond the scope of this paper but representative examples will be used. 
Style is often taken as a synonym for form, as opposed to substance or content. As with most definitions, extreme cases are clear enough and problems arise only with borderline cases. It is only in rare instances that a given substance can be cast in different, mutually interchangeable shapes. In his Exercices de style, R. Queneau reworded the same short paragraph in 150 different ways. On reading them, one can only wonder about the exact nature of the changes involved. To say that stylistic changes involve syntactic and semantic changes is tautological and frustrating. Those variations make sense in a larger, pragmatic context/system and some of the questions to be addressed are: What are the intended effects of an utterance? What is the social position of the speaker/ addressee? What are the social conventions regulating the production of utterances in terms of topic, treatment, etc.? Are such conventions homogeneous within one language? Are they transferable to another language?

In addressing these questions, I will adopt an operational definition of style as that which, in an utterance's form, results from an interaction between the various levels (phonetic, morphological, syntactic, semantic) of the linguistic system and, on the other hand, the pragmatic factors that determine the selection of those linguistic elements. Such a definition assumes the possibility of a choice in the selection of a given utterance and the presence of norms.

Within this framework, we will be able to characterize scholarly writing not only in indispensable linguistic terms, but also in discursive terms: Who is saying what to whom, for what purpose? In what circumstances? Etc. Designing such a framework is in itself a major undertaking and is besides our point here. The framework needed here could be along the lines of what Crystal and Davy proposed for English and Sandig for German. Since this paper does not aim at a full-scale comparative description of scholarly writing in English and French, we will limit ourselves to the identification of the most typical features of that category of text.

The lexicon is probably the most visible identifying feature. It is no accident that Foucault himself spoke of the vocabulaire entortille used by philosophers. ${ }^{1}$ Scholarly writing seems to be the only register of contemporary language where one comes across lexical units such as d'entrée de jeu, questionnement, se donner comme, véhiculer, cauitonner, récuser, s'investir de, évacuer, repérer, s'articuler autour de, etc., and infinitives or past participles used as substantives: le vouloir, le dire, l'impensé, le non dit. To be sure, these features are also found in scholarly speech, but scholarly writing displays other features which may be a little less obvious: sentences are usually long and complex and may exhibit inversions, buildups of near-synonyms, fronting, etc. Very familiar examples are texts written by Lacan, Derrida, Greimas, Foucault, but less familiar authors also illustrate this kind of writing. Here is, for example, a short passage from Trân Duc Thao's Recherches sur l'origine du langage et de la conscience: ${ }^{2}$

Or c'est cette dialectique même, où la réciprocité du signe s'absorbe dans la forme de l'identité, qui engendre la structure du vécu où se constitue le rapport à soi comme conscience. La conscience se présente identiquement comme conscience de l'objet et conscience de soi. Comme conscience de l'objet, elle est image de l'objet posé comme extérieur à elle. Comme conscience de soi, elle est image de cette image ou image d'elle-même en elle-même. Naturellement, quand nous parlons de la conscience comme d'une image de l'objet, nous l'entendons au sens actif, comme acte producteur d'image. Or dans le mouvement de l'indication à soi-même, tel qu'il vient de prendre naissance, le sujet se donne à lui-même une image de l'objet dans sa détermination la plus élémentaire mais aussi la plus fondamentale, à savoir son extériorité objective, détermination où il se présente comme le «ceci! ! et en même temps cet acte, qui constitue l'image perceptive de l'objet, a sa propre image dans le mouvement des autres identifiés avec lui-même, de sorte que cette image de lui-même que le sujet trouve dans les autres, se présente comme intérieure à lui-même. 
The long, complex sentences mentioned above are present, as are some of the typical words and word associations: le vécu; la réciprocité du signe s'absorbe dans la forme de l'identité; le rapport à soi comme conscience; une image de l'objet dans sa détermination la plus élémentaire mais aussi la plus fondamentale, etc.

This example sheds some more light on the notion of scholarly writing, ${ }^{3} \mathrm{Com}$ paring scholarly writing in French and English indeed raises some methodological questions, due both to the nature of definitions and to the object to be defined. Unless we accept a dogmatic definition, we will have to find some balance between a descriptive and a prescriptive definition. This also implies that there is bound to be some circularity in our approach: if we were to describe scholarly writing on the basis of a corpus, we would need criteria to build this corpus in the first place, and these criteria would have to be derived from the definition of scholarly writing that this corpus would be supposed to illustrate.

What scholarly writing suggests to the educated speaker of French is a kind of writing characterized by an elaborately crafted formulation that gives it a quasi - if not fully - literary/artistic quality. Words like suggests and quasi - if not fully clearly indicate degrees of formal sophistication, which makes the identification of scholarly texts very difficult. They also indicate the importance of the linguistic medium in the definition of the literary art. But it is clear enough that this formal sophistication may be the only area where literature and scholarly writing overlap. The differences between them are major and can be shown by further analysis of the notions of literature and scholarly writing. Scholarly writing does not typically refer to scientific writings of the kind produced by so-called exact sciences, but typically refers to documents in the fields of history, anthropology, sociology, philosophy, linguistics, etc. None of these, admittedly, qualifies as literature, which can be more adequately identified by the division into traditional genres.

An even more detailed analysis of scholarly writing in terms of the specific objects discussed by sociology, psychology, etc., would not tell us anything significantly different, mostly because the definition of object would raise even more questions and would fail to provide a definitive, unquestionable solution. The questions raised would be of the following type: Would humanism or the geographic mobility of executives in the EEC be good, typical examples? Can an object be general or does it have to be specific? Does an object have to be associated with a specific discipline? Is the geographic mobility of executives in the EEC an object for philosophers to investigate?

Is the approach to the object a better criterion for the definition of scholarly writing? As a rule, scholarly writing does not use quantitative data though it certainly draws on rational principles such as inference, coherence, non-contradiction, etc.; but obviously, this is not a distinctive feature of scholarly writing since these principles are at work in other kinds of documents as well.

The definition of scholarly writing, in other words, illustrates the difficulty of most, if not all, prescriptive definitions: if the core of a notion is a rather straightforward thing to define, its limits are necessarily blurred.

Given our purpose, however, we have to limit the discussion while avoiding arbitrariness and, in this light, selecting philosophy as a typical example would seem to be ideal. But what we called formal sophistication, the key feature in this description of French scholarly writing, still needs to be defined.

Formal sophistication suggests a particular emphasis on the form of a message, just what Jakobson took as a criterion of the poetic function. In his perspective though, this emphasis was there for its own sake, which is to say that sophistication by itself does not turn a text into a candidate for the poetic function. This point is relevant in so far as it suggests the function of this sophistication and gives us an insight into its real nature. 
Formal sophistication, or ornateness, is relatively simple to identify and measure. It can be described in terms of sentence length, which usually correlates with the complexity of sentence structure, in terms of word frequency, or in terms of the unpredictability of the text, which can be seen as a measure of its semantic density and, indirectly, of its style. In this connection, it is interesting to quote one of the conclusions of a report on sentence length in the Brown Corpus: long sentences appear where

it is necessary for the author to make highly precise statements that exclude a set of further possibilities, i.e. the statements are likely to be modified for the purposes of exactness. The most outstanding example of this factor is genre $\mathrm{H}$, half of which is made up of samples from technical governmental legal statements in which every possible loophole on one subject must be stopped before another subject is introduced. Genre $G$ (learned and scientific writings) also exhibits this factor by virtue of the highly specialized sorts of information exchanged by cognoscenti in a subject field."4

To serve its purpose, however, the criterion of formal sophistication should be univocal and enable us to identify unequivocally what we are referring to as French scholarly writing. But long sentences, uncommon words and semantic density are all features that also characterize legal and technical texts as well as scholarly ones. On the other hand, if ornateness is defined in such terms that it reflects an aesthetic concern with language and includes also typically literary features such as figures of speech, it is bound to narrow the scope of eligible texts.

There is also, of course, a quantitative dimension to this criterion. How many figures of speech - and maybe also which ones? - should a text contain to qualify as scholarly writing? And because our purpose is to compare French and English scholarly writing, this quantitative dimension should be analyzed in both languages. Hence, another circular argument: to answer these questions precisely, we would need to analyze samples of French and English scholarly writing, which would have to be identified precisely by the criteria we are trying to define.

Again, given our purpose, a solution seems to be the analysis of typical samples, and again, philosophy would seem to make an ideal example. A comparison of French and English samples on the same criteria should indicate whether or not the notion of scholarly writing covers the same reality in English and in French. In order to avoid circularity and questionable generalizations, however, the question should be formulated as: "Do the writings of philosophers as philosophers display the same degree of formal sophistication in English and in French?"

The approach to this question will be twofold. As a first step, we will identify formal sophistication in a passage from M. Foucault's Ceci n'est pas une pipe and analyze the English translation of the passage. As a second step, we will analyze two French versions of the same passage from H. Dreyfus and P. Rabinow's "What is maturity? Habermas and Foucault on 'What is Enlightenment?"'

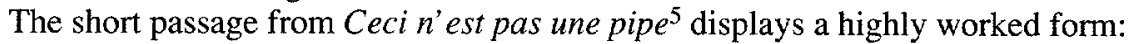

Traquant deux fois la chose dont il parle, il lui tend le piège le plus parfait. Par sa double entrée, il garantit cette capture, dont le discours à lui seul ou le pur dessin ne sont pas capables. Il conjure l'invincible absence dont les mots ne parviennent pas à triompher, en leur imposant, par les ruses d'une écriture jouant dans l'espace, la forme visible de leur référence: savamment disposés sur la feuille de papier, les signes appellent, de l'extérieur, par la marge qu'ils dessinent, par la découpe de leur masse sur l'espace vide de la page, la chose même dont ils parlent. Et en retour, la forme visible est creusée par l'écriture, labourée par les mots qui la travaillent de l'intérieur, et, conjurant la présence immobile, ambiguë, sans nom, font jaillir le réseau des significations qui la baptisent, la déterminent, la fixent dans 
l'univers des discours. Double trappe; piège inévitable: par où échapperaient désormais le vol de oiseaux, la forme transitoire des fleurs, la pluie qui ruisselle?

A convenient way of identifying the figures of speech that contribute to the elaborate form of this passage is to rephrase it in a simplified form, as follows:

Le calligramme les [les plus vieilles oppositions de notre civilisation] neutralise. Il y parvient grâce à sa double nature alors que le discours ou le dessin à eux seuls n'en sont pas capables. Il parvient à exprimer l'absence que les mots ne peuvent dire en leur imposant, par son tracé, la forme visible de leur référent. Les signes disposés sur la feuille de papier évoquent, par leur forme, la chose même dont ils parlent. De manière complémentaire, la forme visible est marquée par les mots, qui évoquent les significations qui la fixent dans l'univers du discours.

Even in this simplified form, the passage can readily be described as scholarly but the simplification has identified some of the processes that account for its sophistication: an extended metaphor centred on the notion of a trap, expressed by such words as traquant, piège, capture, ruses, trappe; another metaphor centred on the idea of a fight: l'invincible absence (the front position of the adjective emphasizes the sophistication), dont les mots ne parviennent pas à triompher par les ruses de l'écriture; an agricultural metaphor expressed by words like creusée par l'écriture, labourée par les mots qui la travaillent ... et font jaillir...; and various segments where Foucault accumulates words: de l'extérieur, par la marge qu'ils dessinent, par le découpage de leur masse sur l'espace vide de la page ...; ; la présence immobile, ambiguë, sans nom; le réseau des significations qui la baptisent, la déterminent, la fixent.

Identifying the stylogenous zones of a document has two kinds of implications. On the one hand, if it could be shown that the presence of figures of speech is typical of French philosophical writing, just as their absence might be of equivalent texts in English (numerical data would, of course, be necessary), we might have identified the distinctive feature that differentiates this kind of prose in the two languages.

On the other hand, the identification of those zones would also be the identification of translation difficulties, as one cannot expect figures of speech to transfer automatically from one language to another. This identification process could be used as a measure of how alien two texts are, since it would map discrepancies between the systems underlying two texts. Specifically, this would address the question raised by the translation into English of French structures like un vouloir, le vécu, le perçu, l'impensé, le trop de pouvoir, etc., which not only express original concepts but draw in a unique fashion on the linguistic structure of French and cannot be transferred to English in equivalent terms.

The translation of the passage follows: ${ }^{6}$

Pursuing its quarry by two paths, the calligram sets the most perfect trap. By its double function, it guarantees capture, as neither discourse alone nor a pure drawing could do. It banishes the invincible absence that defeats words, imposing upon them, by the ruses of a writing at play in space, the visible form of their referent. Cleverly arranged on a sheet of paper, signs invoke the very thing of which they speak - from outside, by the margin they outline, by the emergence of their mass on the blank space of the page. And in return, visible form is excavated, furrowed by words that work at it from within, and which, dismissing the immobile, ambiguous, nameless presence, spin forth the web of significations that christen it, determine it, fix it in the universe of discourse. A double trap, unavoidable snare: How henceforth would escape the flight of birds, the transitory form of flowers, the falling rain?

Examination of the translation indicates that the trap metaphor has been successfully rendered: pursuing its quarry, trap, capture, ruses, trap (again), snare. The rendering of the agricultural metaphor appears as a more qualified success since the image of irrigated 
fields suggested by French (font jaillir le réseau des significations) seems more neutral in English: spin forth the web of significations. But then, was the notion of irrigation really the one Foucault had in mind? A familiar question to any translator, and one which only the author could answer. The idea of a fight comes through readily with such words as banish, invincible, defeats, ruses. The accumulations have been transposed.

If the translation of the passage has resulted in losses, they are admittedly minor. Some passages would definitely be more problematic, for instance when puns are involved: Foucault, commenting on Magritte's drawing of a pipe with the caption Ceci n'est pas une pipe, says "Rien de plus facile à prononcer - notre langage le sait bien - que le nom d'une pipe" 7 . Nom d' une pipe is obviously polysemic, referring both to its literal meaning and to a mild swear-word. This polysemy is not present in the English translation: "Nothing is easier to say - our language knows it well in our place — than the name of the pipe!"

\section{Le calligramme défait}

Le dessin de Magritte (je ne parle pour l'instant que de la première version) est aussi simple qu'une page empruntée à un manuel de botanique; une figure et le texte qui la nomme. Rien de plus facile à reconnaître qu'une pipe, dessinée comme celle-là; rien de plus facile à prononcer - notre langage le sait bien à notre place - que le «nom d'une pipe». Or ce qui fait l'étrangeté de cette figure, ce n'est pas la «contradiction» entre l'image et le texte.

\section{The Unraveled Calligram}

Magritte's drawing (for the moment I speak only of the first version) is as simple as a page borrowed from a botanical manual: a figure and the text that names it. Nothing is easier to recognize than a pipe, drawn thus; nothing is easier to say - our language knows it well in our place - than the "name of a pipe". Now, what lends the figure its strangeness is not the "contradiction" between the image and the text.

In the passage then (and for that matter, in the whole book), figures of speech have been rendered but the general impression to the English-speaking reader is one of unusual stylistic recherche.

The second part of the argument confirms this impression about French scholarly writing. The English passage here is a philosophical text by P. Dreyfus and P. Rabinow dealing with enlightenment as seen by Foucault and Habermas: "What is Maturity? Habermas and Foucault on 'What is Enlightenment?"'8

Two hundred years ago, in 1784 , Kant responded to the question posed by a Berlin newspaper: "What is enlightenment?", by equating enlightenment with the attainment of maturity through the use of reason. Since then the meaning of this claim has been debated periodically. Today the question has again been raised in the public arena by the two thinkers who could legitimately be called the heirs to this debate, because they embody two opposed but equally serious and persuasive ways of reinterpreting the philosophic life through understanding the relation between reason and the historical moment. The question also lies behind the writing of those anti-thinkers who, in the name of post-enlightenment and postmodern discourse, question seriousness in general.

The bulk of this paper will be concerned with the confrontation about "seriousness" which has opposed Michel Foucault and Jürgen Habermas on the legacy of the enlightenment. Foucault's untimely death cut short this important emerging debate cast in terms of the relation between society, critical reason and modernity. But even had Foucault lived, this debate was unlikely to have become a true dialogue because each of these thinkers understands these terms and their relationship in incompatible ways. Both see society as in some way primary but they differ profoundly as to what a modern society is and could be. They 
both acknowledge that an understanding of critical reason is an essential task of contemporary philosophy but they understand critique and reason in radically different ways. And finally both agree with Kant that maturity is the task of the modern age, but Habermas's and Foucault's concepts of modernity and maturity stand in clear opposition. And both stand in opposition to the anti-thinkers.

Foucault and Habermas agree with Kant that critical reason begins with the rejection of the Western project of developing a theory which mirrors substantive universal truths about human nature. Foucault and Habermas also agree with Kant that the problem of moral action and social bonds must be faced anew once revealed religion and metaphysics have lost their authority. Both accept that maturity consists in man's taking over responsibility for using his critical rationality, and that critical rationality consists in the unflinching examination of our most cherished and comforting assumptions. Thus Kant was able to articulate a fundamental change taking place in Western understanding which still gives his philosophy contemporary relevance.

From here on Foucault's and Habermas's interpretation of the significance of critical reason, society and modernity and their relation diverged dramatically. For Habermas, Kant's modernity consists in his recognition of the limits of reason, i.e., in his rejecting reason's dogmatic claim to provide truth about transcendent reality. Kant's maturity consists in showing us how to save the critical and transcendental power of reason and thus the triumph of reason over superstition, custom, and despotism - the great achievement of the enlightenment.

Habermas's updated version of Kant's philosophy claims that a pre-critical attempt to offer a metaphysical grounding can be replaced with an analysis of the conditions in which the ideal speech community presupposed in all uses of language can be realized. Habermas argues that this analysis of the conditions for validating truth is the way to unify critical reason and social concerns, and thereby answer Kant's challenge. This account of a communicative use of language is essentially intellectualist. One must be able to reach agreement about valid claims on the basis of the reasons offered in the justification of the propositional content, the truthfulness or sincerity of the intentional expression and rightness or appropriateness of the speech act. The analysis of these universal social conditions necessary for the undistorted use of language provides the procedural normative criteria by which one can evaluate social organizations. Immaturity for Habermas is the failure to recognize and advance the increasing explicitness of the "assumptions" underlying communicative practice. It leaves us open to the dangerous seductions of phronesis, art and rhetoric - ways of communicating and reaching agreement which, according to Habermas, our culture has outgrown. Maturity consists in clarifying the form social organizations take in a given epoch, judging their adequacy for promoting human community, and assuming responsibility both for the way they are and for making them more adequate.

For Habermas, then, the problem of modernity, a unique historical problem, consists in preserving the primacy of reason articulated most recently and fully in Kant's enlightenment critique while facing up to the loss of metaphysical ground of our substantive beliefs. Maturity is the discovery of the quasi-transcendental basis of community as all we have and all we need, for philosophy, and human dignity.

This passage is not familiar in style but neither is it formal; and above all, it displays none of the rhetorical fireworks of the Foucault passage. Assuming that a translator or interpreter should render a message in a style equivalent to the original one, it would seem reasonable to project those features onto the French version.

The interest of this text is that two translations of it were done, totally independently, which are stylistically very different, one being very ornate, the other not. Here they are:

C'est il y a deux siècles, en 1784 , que Kant, répondant à la question que posait une revue berlinoise: Qu'est-ce que les lumières? identifia le progrès des Lumières à l'accession à l'âge d'homme, par l'usage de la raison. Depuis lors, on n'a pas manqué de disputer du sens auquel cette thèse devait être entendue, et d'en reprendre régulic̀rcment l'instruction. $\grave{A}$ l'heure actuelle, la question revient en délibéré auprès du public, à l'instance des deux 
penseurs pouvant prétendre, à bon droit, au titre d'héritiers de ce débat, en ce qu'ils incarnent deux modes opposés, mais également garants de sérieux, et emportant une égale conviction, de se pourvoir en réinterprétation de ce qu'est la vie philosophique, motivés par l'appréhension de la relation intervenant entre raison et moment historique. Et c'est d'ailleurs cette même question qui sous-tend les écrits de ces anti-penseurs qui, arguant du discours de la postmodernité et de la post-Aufklärung, remettent en cause l'esprit de sérieux en son principe général.

L'essentiel de notre propos, en ce mémoire, sera de considérer le différend qui a mis en présence, sur la question de l'«esprit de sérieux», Michel Foucault et Jürgen Habermas, différend portant sur ce que nous ont légué les Lumières. La mort de Foucault a mis un terme brutal au débat capital qui s'engageait, quant à la relation intervenant entre société, raison critique, et modernité. Mais, quand bien même Foucault fût resté en vie, il est peu probable que la controverse eût abouti à un authentique dialogue, dès lors que chacun de ces penseurs s'était fait de ces termes, et des relations intervenant entre eux, une idée distinctive, relevant d'une incompatibilité réciproque. S'ils s'accordent, tous deux, à considérer que la société est en quelque sorte première, leur divergence est profonde, lorsqu'il s'agit de dire ce qu'est une société moderne, et d'envisager ce qu'elle pourrait être. S'ils souscrivent, l'un comme l'autre, à l'idée que l'une des tâches essentielles de la philosophie est de comprendre, et de donner à entendre, ce qu'est la raison critique, c'est en des sens foncièrement différents qu'ils entendent et la raison, et la critique. Enfin, s'ils tombent d'accord, l'un et l'autre, avec Kant, pour estimer que c'est l'accession à l'âge d'homme, à la maturité (Mündigkeit), qu'il incombe aux temps modernes d'accomplir, les concepts respectifs de modernité et de maturité, chez Habermas et chez Foucault, s'opposent terme à terme. Moyennant quoi, ces auteurs s'opposent, tant l'un que l'autre, aux anti-penseurs.

Foucault et Habermas s'accordent, avec Kant, à découvrir, au principe de la raison critique, l'abandon du projet qui avait été celui de la pensée occidentale, de mettre en place une théorie qui serait reflet de vérités éternelles, d'ordre substantif, pour ce qui est de la nature humaine. Foucault et Habermas s'accordent encore avec Kant, en ce qu'ils estiment que le problème de l'action morale et du lien social doit être envisagé à nouveaux frais, dès lors que la religion révélée et la métaphysique sont déchues de leur autorité. L'un autant que l'autre, ils tiennent pour acquis que la majorité, pour l'homme, consiste à prendre la responsabilité de faire usage de sa faculté de raison critique, et que cette rationalité critique s'exerce dans l'examen intransigeant des présupposés qui nous sont les plus chers, et du plus grand réconfort. $\grave{A}$ ce titre, Kant a su articuler une mutation fondamentale, s'effectuant dans l'entendement occidental, assurant à sa philosophie son actualité à ce jour.

Ceci posé, dans les interprétations que mettent en place Foucault et Habermas, quant à la signification, et quant à la portée, envisageables, pour ce qui est de la raison critique, de la société et de la modernité, se fait jour une divergence radicale. Pour Habermas, la modernité de Kant tient à ce qu'il a su reconnaître les limites de la raison: en d'autres termes, à ce qu'il a récusé la prétention dogmatique de la raison, de fournir des vérités, concernant ce qui est réalité transcendantale. La maturité de Kant tient à ce qu'il nous montre comment conserver à la raison son pouvoir critique, de transcendance, et, par là même, comment assurer le triomphe de la raison sur la superstition, sur l'habitude, et sur le despotisme - ce triomphe qui reste le grand acquis des Lumières.

Telle mise à la page, par Habermas, de la philosophie kantienne se fait fort d'assurer la relève d'une entreprise précritique de fondation métaphysique, par la mise en place d'une analyse des conditions requises pour que la communauté linguistique idéale, que présuppose toute utilisation du langage, puisse devenir réalité. Habermas fait valoir que c'est par recours à une telle analyse des conditions de validation de la vérité que l'on saura effectuer l'unité de la raison critique et du projet social, et répondre ainsi à la mise en demeure kantienne. Pareille façon de rendre compte de l'utilisation communicationnelle du langage est d'ordre essentiellement intellectualiste. Il faut que l'on soit en mesure de parvenir à un consensus quant à la validité d'une affirmation, sur l'assiette des raisons alléguées en justification du contenu propositionnel; de la véracité, ou de la sincérité des expressions intentionnelles; et de la justesse, ou du caractère approprié, de l'acte de langage. C'est l'analyse de ces conditions 
sociales universelles, nécessaires pour une utilisation non déformée du langage, qui fournit les critères normatifs, d'ordre procédural, permettant l'évaluation des formes d'organisation sociale. L'état de minorité, au sens de Habermas, est inaptitude à prendre en compte, et à promouvoir, l'explication croissante des «prémisses» sous-tendant la pratique communicationnelle. En cet état, nous restons sans défense, face aux insidieux sortilèges de la phronésis, de l'art et de la rhétorique - de modes de communication, et d'établissement d'un consensus, que notre civilisation, au dire de Habermas, a dépassés. L'âge d'homme, la maturité, est élucidation des formes que revêtent les structures sociales, à une époque donnée, évaluation de leur aptitude à promouvoir la communauté humaine, et assomption de la responsabilité, tant de leur mode d'être actuel, que de leur transformation aux fins d'en parfaire l'adéquation.

Ainsi donc, pour Habermas, le problème de la modernité, en tant que problème historique singulier, est celui de la sauvegarde du primat de la raison — tel que l'a articulé sous la forme la plus complète, et la plus récente, la critique kantienne, faisant fonds sur les Lumières -, par une démarche intégrant le déficit de fondement métaphysique de nos convictions substantives. La majorité, l'âge d'homme, vient avec la découverte de l'assise, d'ordre quasi transcendantal, de la communauté, en tant qu'elle est la seule disponible, et seule requise, pour la philosophie, et pour la dignité humaine.

$\infty \infty \infty \infty \infty \infty \infty \infty$

Il y a deux cents ans, en 1784 , Kant répondait à la question «Qu'est-ce que les lumières ?» qu'avait posée un journal berlinois, en les définissant comme l'accès à la maturité par l'usage de la raison. Depuis lors, le sens de sa formule a fait l'objet de controverses périodiques. Or, la question est aujourd'hui posée publiquement par les deux penseurs en qui on pourrait voir les héritiers légitimes de ce débat, car ils incarnent deux manières opposées mais également sérieuses et convaincantes, de réinterpréter la vie philosophique en examinant le rapport entre raison et moment historique. La même question parcourt les écrits de ces anti-penseurs qui, au nom de l'après-lumières et du discours postmoderne, mettent en question le sérieux en général.

Ce qui nous occupera essentiellement, c'est la divergence de vues sur le «sérieux» qui a opposé Michel Foucault et Jürgen Habermas dans la question de l'héritage des lumières. La mort prématurée de Foucault a écourté cet important débat axé sur le rapport entre société, raison critique et modernité. Mais à supposer que Foucault ait vécu, il y a peu de chances que ce débat se soit transformé en véritable dialogue car les sens que l'un et l'autre donnent à ces termes et à cette relation sont incompatibles. Tous deux accordent à la société une certaine primauté mais ils diffèrent profondément dans leur définition de ce qu'est et pourrait être une société moderne. Ils s'accordent à dire qu'une des tâches essentielles de la philosophie contemporaine est de comprendre la raison critique mais ils ont de la critique et de la raison des conceptions radicalement différentes. Tous deux, enfin, posent, avec Kant, que la maturité est la tâche de l'époque moderne, mais les concepts de modernité et de maturité chez Habermas et Foucault sont radicalement divergents. Tous deux, par ailleurs, s'opposent aux anti-penseurs.

Pour Foucault et Habermas, comme pour Kant, la raison critique s'appuie sur l'abandon du projet, propre à la pensée occidentale, d'élaborer une théorie qui refléterait des vérités universelles essentielles sur la nature humaine. Selon eux, et selon Kant encore, il faut réexaminer le problème de l'action morale et des liens sociaux dès l'instant où la religion révélée et la métaphysique perdent leur autorité. Pour l'un comme pour l'autre, il y a maturité lorsque l'homme prend en mains l'usage de sa rationalité critique, et cette rationalité critique suppose l'examen impitoyable de nos principes les plus chers et les plus rassurants. C'est ainsi que Kant a réussi à exprimer un changement fondamental dans la pensée occidentale qui donne à sa philosophie toute son actualité.

À partir de là, l'interprétation que donnent Foucault et Habermas du sens de la raison critique, de la société, de la modernité et de leur rapport divergent considérablement. Pour Habermas, la modernité de Kant consiste à reconnaître les limites de la raison, c'est-à-dire à 
rejeter la prétention dogmatique de la raison à fournir des vérités sur la réalité transcendante. La maturité de Kant consiste à nous montrer comment sauver le pouvoir critique et transcendantal de la raison, et donc à nous montrer le triomphe de la raison sur la superstition, la coutume et lè despotisme - le grand progrès des lumières.

Aux termes de la philosophie kantienne mise à jour par Habermas, on peut substituer au fondement métaphysique que proposaient les penseurs précritiques une analyse des conditions où peut se réaliser la communauté de parole idéale que supposent tous les usages du langage. Selon Habermas, cette analyse des conditions de validation de la vérité est la démarche qui permettra d'accorder la raison critique et les préoccupations sociales, et ainsi de répondre au défi de Kant. Cette conception de l'usage communicatif du langage est essentiellement intellectualiste. On doit pouvoir arriver à un accord sur ce qu'il est possible d'affirmer valablement en partant des raisons qu'offrent la justification du contenu propositionnel, la véracité, la sincérité de l'expression intentionnelle et la justesse, le caractère approprié de l'acte de parole. C'est dans l'analyse de ces conditions sociales universelles nécessaires à un usage non déformé du langage que l'on trouvera les critères d'évaluation des organisations sociales. L'immaturité, pour Habermas, est l'incapacité à reconnaître et à faire progresser le caractère de plus en plus explicite des «principes» sous-jacents à la pratique communicative. Elle nous laisse en proie aux dangereuses séductions de la phronesis, de l'art et de la rhétorique - façons de communiquer et de s'entendre que, selon Habermas, notre culture a dépassées. La maturité consiste à mettre en lumière la forme que revêtent les organisations sociales d'une époque donnée, à juger leur aptitude à promouvoir la communauté humaine, à assumer la responsabilité de ce qu'elles sont tout en les rendant plus adéquates.

Pour Habermas donc, le problème de la modernité, problème historique unique, est de préserver le primat de la raison dont la critique de Kant a constitué l'expression la plus complète et la plus récente, tout en faisant face à la perte du fondement métaphysique de nos croyances essentielles. La maturité est la découverte du fait que l'assise quasi transcendantale de la communauté est tout ce que nous avons et tout ce que requièrent la philosophie et la dignité humaine.

The first translation has as its title: "Habermas et Foucault. Qu'est-ce que l'âge d'homme?"' This very phrase, l'age d' homme, is a first indication of stylistic sophistication. More clues follow. In the first paragraph, a succession of legal phrases are used: reprendre l'instruction; revient en délibéré; se pourvoir en réinterprétation; arguant du discours; and thus constitute an extended metaphor, whereas the original text used only standard words and phrases relevant to intellectual activity: claim, debate, raise a question, to reinterpret, understanding, the relation between. Also, some French sentences have a complex structure: "on n'a pas manqué de disputer du sens auquel cette thèse devait être entendue et d'en reprendre régulièrement l'instruction" whereas the original English sentence was much simpler: "The meaning of this claim has been debated periodically". Another example: "by the two thinkers who could legitimately be called the heirs to this debate, because they embody two opposed but equally serious and persuasive ways of reinterpreting" is rendered: "à l'instance de deux penseurs pouvant prétendre, à bon droit, au titre d'héritiers de ce débat en ce qu'ils incarnent deux modes opposés mais également garants de sérieux et emportant une égale conviction, de se pourvoir en réinterprétation". And yet another: "through understanding the relation between reason and historical raoment" has become "motivé par l'appréhension de la relation intervenant entre raison et moment historique".

This translation, in other words, does not match the original style, which is far less recherché. More details point to the same conclusion. This paper, a very common phrase indeed, has been rendered through the words en ce mémoire, which is far more elaborate than the original, both because of the uncommon mémoire and the equally uncommon use of the preposition en in such a structure. More examples along the same lines would be: 
Quand bien même Foucault fût resté en vie; une théorie qui serait reflet de; le problème de l'action morale et du lien social doit être envisagé à nouveaux frais; la mise en demeure kantienne; sur l'assiette des raisons; assomption de la responsabilité; le déficit ${ }^{10}$ de fondement métaphysique.

This is no doubt a brilliant translation but its sophistication raises questions, given the low profile of the original text. On the other hand, this sophistication is highly revealing in that it confirms the desirability of ornateness in French philosophical writing. It also sheds light on what the translator assumed are the French readers' expectations and therefore emphasizes the importance of style in the translated text. Given one type of text in two languages, and given that this type of text does not exhibit the same stylistic features in both, should a text from one language conform to the style that is typical of this type of text in the other language? The translation above obviously assumes a positive answer to this question.

The other translation of this passage is less elaborate and shows a lower profile which matches that of the original text. The first paragraph reads as follows: "Depuis lors, le sens de sa formule a fait l'objet de controverses périodiques. Or, la question est aujourd'hui posée publiquement par les deux penseurs en qui on pourrait voir les héritiers de ce débat, car ils incarnent deux manières opposées mais également sérieuses et convaincantes, de réinterpréter la vie philosophique en examinant le rapport entre raison et moment historique".

The word paper, rendered as mémoire in the first version has been obliterated. Further down, the problem of moral action and social bonds must be faced anew has become il faut réexaminer le problème de l'action morale et des liens sociaux. Further on still, sur l'assiette des raisons in the first version and en partant des raisons in the second translate on the basis of these reasons.

One more example will be the rendering of a more complex sentence: Maturity consists in clarifying ... judging ... and assuming responsibility. The first rendition is $L$ 'a $a g e$ d' homme, la maturité est ... élucidation, ... évaluation, ... et assomption de la responsabilité. The second version is, again, less elaborate: La maturité consiste à mettre en lumière ..., à juger ..., à assumer.

In the light of these examples, we can now return to the initial question.

The assumption was that French scholarly writing refers to a category of texts from the social sciences characterized by a high degree of verbal elaboration. The question was whether English texts of a similar nature display equivalent formal recherche. The intuitive answer suggested was negative. Because of the methodological difficulties involved in providing a precise definition of scholarly writing, we decided to narrow the scope of the question and chose to look at philosophical texts, which unquestionably constitute a typical example of scholarly writing. One of the French translations of the English passage selected was particularly revealing since its sophistication, which does not match the style of the original, low-key text, points to the translator's perception of a low-key translation as inadequate for his French audience. We can only assume that he provided an elaborate translation because, in his eyes, this would give the new text the look that readers expect.

A few conclusions can be drawn from this. First of all, the notion of formal sophistication should be clarified. To be sure, philosophical texts and, in a wider perspective, scholarly writing, display long sentences and unusual or new words. But how could it not be so? Long sentences are usually complex, and they are so because the thought they express is itself complex. The concepts used are unusual or even totally new and therefore call for unusual or new words. This can readily be confirmed by a substitution test. All things being equal, can a rare or new word be replaced with an ordinary one? Can a complex structure be broken down into a number of simple ones? If these changes are not 
irrelevant, it is reasonable to say that such elaboration is functional and that this is why it is also found in legal or technical texts.

This formal elaboration, then, by contrast, suggests that some ornateness, such as the typical sophistication of the French texts that we have examined, may not be functional. But functionality is by definition relative. So, if this sophistication may not be justified in linguistic terms, we may have to look for an explanation on an extra-linguistic terrain.

The extra sophistication present in French scholarly writing is not without effects. As a matter of fact, it causes a powerful effect: it singles out a type of writing, places it above ordinary texts and turns it into something impressive, comparable to sumptuous ceremonies or carefully wrought decorative elements in architecture. It turns the text, as it were, into some sort of sacred / artistic object.

On the other hand, it should be remembered that this type of text is produced by intellectuals, a social group that Bourdieu places among the dominating classes where they occupy, however, a dominated position. Naturally, intellectuals tend to improve or at least preserve their status, and can best achieve this through the materialization of their intellectual production, in other words through their writings. Their production has both form and content. The prestige of content is relative, as the not so mythical antagonism between so-called exact sciences and social sciences suggests, but the prestige and authority of intellectuals rest on both content and form. The point, therefore, is not that linguistic sophistication is merely a strategy covering up for lack of substance. Rather, the point is that it is meant to enhance that substance. Bourdieu approaches language use in terms of economic interaction and points out that "Ces discours ne sont pas seulement (ou seulement par exception) des signes destinés à être compris, déchiffrés; ce sont aussi des signes de richesse destinés à être évalués, appréciés et des signes d'autorité, destinés à être crus et obéis." Interestingly, J.-M. Domenach writes, much to the same effect: "Sans vouloir me lancer dans des explications trop réductrices, je dirai quand même que si tant d'intellectuels français se sont enfermés dans l'hermétisme, c'est par une sorte de panique devant les média de masse, une rétraction sur les parties les plus spécialisées des sciences humaines et sur un travail de critique extrêmement raffiné". ${ }^{12}$

The interpretation proposed is consistent with Bourdieu's description of what he calls les langages d'autorité and les stratégies d'assimilation et de dissimilation sociale, ${ }^{13}$ just as it is consistent with the highly elaborate character of the French translation examined above, as well as with attempts made at simplifying legal language and thus removing from it a good deal of its decorum. ${ }^{14}$ Along the same lines, the fact that scholarly writing is usually not anonymous writing is also relevant. Scholarly texts obviously contribute to their author's social status and their form therefore constitutes a value to be sought. Conversely, this value does not make much sense with anonymous texts, although this is not to say that these cannot display any kind of formal sophistication, both because this sophistication may be there for functional reasons and because even anonymous texts do have authors.

The final question, then, is why this stylistic recherche seems to be present in French more than in English. Several hypotheses must be considered.

As a first hypothesis, one can point out that social differentiation takes on different forms in different societies. Social values differ from one society to another, from one period to another, etc., and it may be the case that verbal sophistication is not valued in English the way it is in French. In fact, this question is part of a more complex and delicate one, which cannot be answered here and relates to the place of sophistication in English-language culture.

This leads to a second hypothesis. That verbal sophistication is a value in English cannot be denied, but it should be seen in shades of grey rather than in black and white. It 
just does not seem to be present in English to the same degree as in French. But this raises a more fundamental question. Is the kind of formal sophistication we have observed in French possible at all in English? And just what kind of sophistication? We have shown that linguistically functional verbal sophistication does exist in English, just like figures of speech. The fact that figures of speech do not translate well is inherent in their nature and does not mean that they are impossible in English. But more specifically, there is a range of phrases such as d'entrée de jeu or se donner comme, which do create translation problems. The difficulties become clearer when one examines the semantic fields covered by these and synonymous phrases. Thus, next to d'entrée de jeu, we have d'entrée, d'emblée, d'abord, dès l'abord, tout d'abord, pour commencer, en premier lieu, etc. It would appear that the equivalent semantic field in English is less densely cut up. In other words, some of what we have called the verbal sophistication of French scholarly writing is structurally impossible in English. The English language itself limits its own possibilities. If this verbal sophistication is possible at all (and it does appear, in spontaneous English scholarly writing, as in Untying the text, for instance), it seems, however, to have been imported. ${ }^{15}$

Hence a final and more precise hypothesis. Could it be that verbal sophistication is not valued in English-language scholarly writing? It seems reasonable to claim, at least, that the dominating intellectual model in the Anglo-Saxon world, in North America especially, is the scientific model, which favours a simple, straightforward, unambiguous mode of expression and does not leave any room for ornamentation. This would explain why Foucault, to name just one author, sounds so foreign when translated in English, but again, this is not to say that verbal sophistication is not possible or does not exist in English. W. Lambdin, the author of the Doublespeak Dictionary, testifies to it when he denounces the convolutions of the language used by administrators and, more generally, intellectuals. ${ }^{16}$ And in his Complete Plain Words, Sir Ernest Gowers, in very similar terms, also denounced the excess of "long or unfamiliar or technical or modish words, arranged in long and involved sentences." 17

These hypotheses do not conflict with each other but, rather, complement each other. If one of them, or even their sum is not satisfactory, it may be because they point to the irreducible differences between two languages and two cultures.

\section{Notes}

1. "Par delà le bien et le mal", Actuel, 14, novembre 1971, p. 44.

2. Trân Duc Thao, Recherches sur l'arigine du langage et de la conscience, p. 25.

3. At the 1988 Sorbonne nouvelle conference on "La mise en relief", J.-R. Ladmiral suggested the term prose de pensée to refer to scholarly writing. It is not easier, and fortunately not more difficult, to define but it is interesting by its perspective on the object, and confirms the approach taken here.

4. Markworth, M.L. \& Bell, L. "Sentence Length Distribution in the Corpus", p. 371.

5. Foucault, M., Ceci n'est pas une pipe, pp. 22-23.

6. Foucault, M., This is not a Pipe. Trans. Harkness, p. 22.

7. Foucault, M. Ceci n'est pas une pipe, p. 17. This is not a Pipe, pp. 8-19.

8. Dreyfus, H. \& Rabinow, P. "What is Maturity? Habermas \& Foucault on "What is Enlightenment?", pp. $109-110$.

9. Dreyfus, H. \& Rabinow, P. "Habermas et Foucault : qu'est-ce que l'âge d'homme ?", pp. 857-859. "Qu'est-ce que la maturité ? Habermas, Foucault et les lumières", pp. 127-129.

10. In his Les Parisiens, A. Schifres dwells a little on the word déficit. His comment is an eye-opener: "Les tics de langage se propagent chez nous à une vitesse inouïe. En 1989, il a suffi d'un mois pour que la classe politique tout entière remplace manque par déficit: cela nous a donné le déficit de démocratie, le déficit d'explication, le déficit de solidarité. Rocard nous parle d'un déficit de coordination. Quant à l'inégalité professionnelle, elle a également disparu : Yvette Roudy la remplace froidement par un déficit d'égalité." (p. 294)

11. Bourdieu, P. Ce que parler veut dire, p. 60 .

12. Domenach, J.-M. "Le Monde des intellectuels", p. 336.

13. Bourdieu, P. Ce que parler veut dire, pp. $103 \mathrm{ff}$. 
14. This observation about decorum is not new. Pascal (Pensées, p. 53) wrote: "Nos magistrats ont bien connu ce mystère. Leurs robes rouges, leurs hermines dont ils s'enmaillotent en chats fourrés, les palais où ils jugent, les fleurs de lys, tout cet appareil auguste était fort nécessaire. Et si les médecins n'avaient des soutanes et des mules et que les docteurs n'eussent des bonnets carrés et des robes trop amples de quatre parties, jamais ils n'auraient dupé le monde, qui ne peut résister à cette montre si authentique. $S$ 'ils avaient la véritable justice et si les médecins avaient le vrai art de guérir, ils n'auraient que faire de bonnets carrés. La majesté de ces sciences serait assez vénérable d'elle-même. Mais n'ayant que des sciences imaginaires il faut qu'ils prennent ces vains instruments, qui frappent l'imagination, à laquelle ils ont affaire. Et par là en effet, ils attirent le respect.

Les seuls gens de guerre ne se sont pas déguisés de la sorte, parce qu'en effet leur part est plus essentielle. Ils s'établissent par la force, les autres par grimace".

15. This opinion is confirmed by R. Bernstein's article "When Parentheses are Transgressive" (New York Times Magazine, July 29,1990, p. 16. See also a response to this in NYTM, Sept. 16, 1990, p. 12). R. Bernstein asks "Was this lingo squirted out by Orwell's cuttlefish or is it really useful?" and comes to much the same conclusion as Bourdieu: "It has a cultish sensuousness to it. As the lit crits might put it, you become part of the transgressive, rather than the dominant discourse. You are a member of the club".

16. Lambdin, W. Doublespeak Dictionary, pp. ix-xii.

17. Gowers, Sir E. The Complete Plain Words, p. 20.

\section{REFERENCES}

BELAVAL, Y. (1952): Les Philosophes et leur langage, Paris, Gallimard.

BOURDIEU, Pierre (1982): Ce que parler veut dire, Paris, Fayard.

BURNIER, M. A. et P. RAMBAUD (1978) : Le Roland Barthes sans peine, Paris, Balland.

CRYSTAL, D. and D. DAVY (1969): Investigating English Style, London, Longmans.

DOMENACH, J.-M. (1981): "Le Monde des intellectuels", G. Santoni, Société et culture de la France contemporaine, Albany, NY, State University of New York Press.

DREYFUS, H. and P. RABINOW (1986) : “Habermas et Foucault. Qu'est-ce que l'âge d'homme?", Trad. J.-F Roberts, Critique, août / sept., pp. 471-472.

DREYFUS, H. and P. RABINOW (1989): "Qu'est-ce que Ia maturité ? Habermas, Foucault et les lumières", Trad. J. Colson, Foucault : Lectures critiques, Bruxelles, Éditions De Boeck.

DREYFUS, H. and P. RABINOW (1986): "What is Maturity? Habermas and Foucault on 'What is Enlightenment?", D.C. Hoy, Foucault: a Critical Reader, Oxford, Basil Blackwell.

FOUCAULT, M. (1973) : Ceci n'est pas une pipe, Paris, Scholiès / Fata, Morgana.

FOUCAULT, M. (1971) : "Par delà le bien et le mal", Actuel, 14, nov.

FOUCAULT, M. (1983): This is not a Pipe, Trans. J. Harkness, Berkeley, University of California Press.

GOWERS, E. (1975): The Complete Plain Words, London, Pelican.

LAMBDIN, W. (1979): Doublespeak Dictionary, Los Angeles, Pinnacle Books.

MARCKWORTH, M. L. and L. BELL (1967): "Sentence Length Distribution in the Corpus", H. Kucera and W.N. Francis (Ed.), Computational Analysis of Present Day American English, Providence, R.I., Brown University Press, pp. 368-405.

FASCAL, B. (1966): Pensées, Paris, Mercure de France.

QUENEAU, R. (1969): Exercices de style, Paris, Gallimard.

SANDIG, B. (?): "Zur Differenzierung gebrauchssprachlicher Textsorten im Deutschen", E. Gülich and W. Raible (Hsgb), Textsorten, München, Athenäum.

SCHIFRES, A. (1990): Les Parisiens, Paris, Éditions Lattès.

TRÂN DUC THAO (1973): Recherches sur l'origine du langage et de la conscience, Paris, Éditions sociales

YOUNG, R. (1986): Untying the Text, Boston, Routledge and Kegan Paul. 